Journal of Agricultural Sciences
(Tarim Bilimleri Dergisi)

\title{
Determination of Pneumatic Conveying Characteristics of Canola Seeds
}

\author{
Refi Ratip ÖZL $\ddot{U}^{a}\left(\mathbb{D}\right.$, Metin GÜNER ${ }^{b^{*}}$ \\ ${ }^{a}$ Republic of Turkey Ministry of Agriculture and Forestry General Directorate of Plant Production, Dumlupinar Boulevard, O6800, Çankaya, Ankara, TURKEY

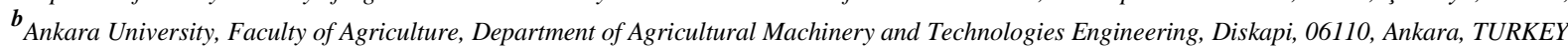

ARTICLE INFO

Research Article

Corresponding Author: Metin GÜNER, E-mail: mguner@ankara.edu.tr

Received: 12 September 2020 / Revised: 17 November 2021 / Accepted: 19 November 2021 / Online: 15 October 2022

ÖZLÜ R R, GÜNER M (2022). Determination of Pneumatic Conveying Characteristics of Canola Seeds. Journal of Agricultural Sciences (Tarim Bilimleri Dergisi), $28(4)$ :656-665. DOI: 10.15832 /ankutbd.794097

\section{ABSTRACT}

In this study, it was aimed to determine the pneumatic conveying characteristics of canola seeds (Brasicca napus Oleifera $s p$ ). The physical properties, pressure drop, air velocity, power consumption characteristics of Turan variety canola seeds were investigated. Three different canola moisture $(6.36 \%, 16.54 \%$ and $25.94 \%)$, three different pipe diameters (43.1, 54.5 and $70.3 \mathrm{~mm})$, three different material feed flow rates $(3.89$, 5.47 and $7.49 \mathrm{t} / \mathrm{h}$ ) and five different air velocities ( 5 compressor cycles of $850,1150,1450,1750$ and $2250 \mathrm{~min}^{-1}$ ) were used and the effects of these factors on the pneumatic conveying characteristics of the canola seeds were examined. The pneumatic conveying of canola seeds was carried out at the positive pressure pneumatic conveyor. The pressure drop and power consumption have increased with the increase of air velocity. The lowest pressure drop and power consumption values were obtained in conveying with pipe diameter of $70.3 \mathrm{~mm}$, canola seed moisture of $16.54 \%$, compressor speed of $1150 \mathrm{rpm}$ and conveying capacity of $3.89 \mathrm{t} / \mathrm{h}$. The lowest power consumption was achieved with the conveying of the canola seed at $6.36 \%$ moisture, $7.49 \mathrm{t} / \mathrm{h}$ material feed flow rate and $1150 \mathrm{rpm}$ compressor speed. In trials, the pressure drop decreased when the pipe diameter was increased.

Keywords: Conveying, Canola seed, Pneumatic, Pressure drop, Physical properties

\section{Introduction}

Canola (Brasicca napus Oleifera sp) forms a group of plants (formerly known as a member of the Cruciferae family) belonging to the Brasscicaceae family. Canola is a special name for a rapeseed variety that edible oil can be produced from its seeds and has been genetically modified by classical breeding methods for this purpose. Canola has high oil content and high adhesion probability. Pneumatic conveying is defined as pulling in the granular material to be transmitted along a transmission pipeline, hanging it in the air and conveying it. It is preferred for its reasons such as being flexible, no transmission loss, being suitable for automation, ensuring continuous flow.

Davison et al. (1975) stated that in case of exposure to any external load, information about the mechanical behavior of canola is required in the design of canola grinding and crushing machines, especially in the selection of grinding drum surfaces. Çalışır et al. (2005) determined some physical properties of canola seed grains such as size, geometric mean diameter, sphericity, 1000 grain weight, bulk density, terminal velocity, projection area and porosity. Razavi et al. (2009) determined the physical properties of four common Iranian varieties of canola seeds (Hyola, Okapi, Orient and SLM) such as average seed length, average diameter, geometric mean diameter, sphericity, bulk density, angles of repose, static coefficient of friction, thousand seed mass as a function of their moisture contents. İzli et al. (2009) investigated the physical and mechanical properties of three common varieties of rapeseed as a function of seed moisture content varying from 8.3 to $25.9 \%$, from 7.7 to $27.4 \%$, and from 7.3 to $26.4 \%$ (d.b.) for cv. Capitol, Jetneuf and Samurai, respectively. Increasing moisture content was found to increase the length, diameter, geometric mean diameter, sphericity, seed volume, surface area, thousand grain weight, porosity, angle of repose and terminal velocity, and static friction coefficient on six structural surfaces, while decreasing bulk density, true density and rupture strength. Kord et al. (2016) reported that canola stems may be an alternative source of raw materials for the particle board industry. Barekati et al. (2019) studied the effects of sowing dates and humic acid foliar application on canola cultivars seed yield and yield components.

The aim of this study is to determine the pneumatic conveying characteristics of canola seeds. Depending on the moisture change of the canola seed, physical properties such as specific mass, porosity, and conveying characteristics such as air velocity, pressure drop, and power consumption have also been determined. 


\section{Material and Methods}

\subsection{Material}

In this study, Turan variety canola seeds (Brasicca napus Oleifera sp) were used. The pneumatic conveying of canola seeds was carried out at the positive pressure pneumatic conveyor shown in Figure 1.

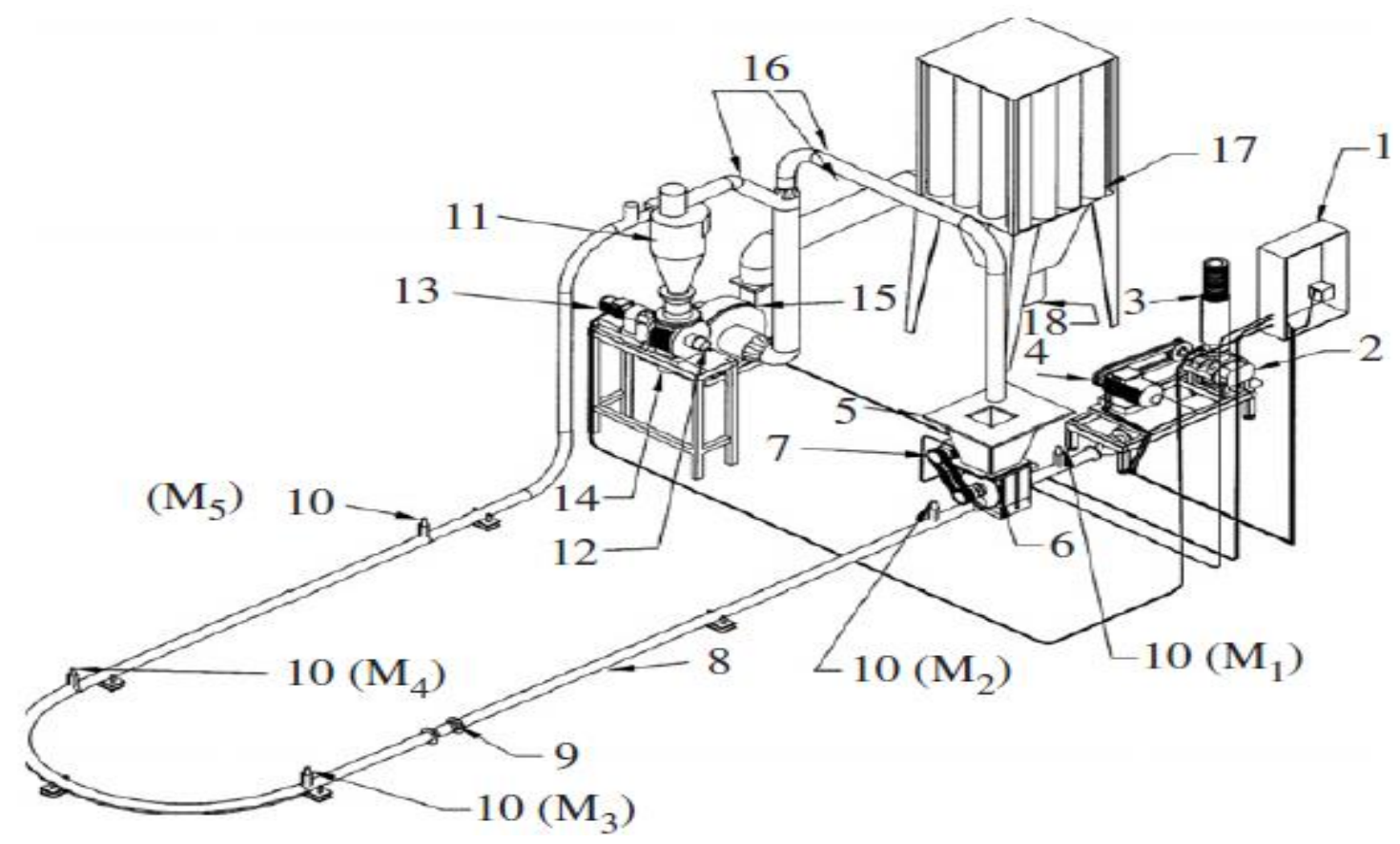

Figure 1- The general arrangement of the positive pressure pneumatic conveyor: 1: control unit; 2: roots blower; 3: air inlet filter; 4: roots blower motor; 5: seed hopper; 6: rotary feeder or hopper airlock feeder; 7: rotary feeder motor; 8: seed pipe; 9: transparent tube; 10: pressure drop measurement (M) tappings; 11: cyclone separator; 12: cyclone separator airlock; 13: cyclone separator airlock motor; 14: seed discharge; 15: vacuum blower; 16: dust pipes; 17: dust collector or exhaust air filter; 18: light foreign materials (Güner 2006).

In the measurement and analysis, $0.01 \mathrm{~g}$ precision electronic precision scale, $0.01 \mathrm{~mm}$ precision electronic digital caliper, 0.1 $\mathrm{ml}$ precision graduated cylinder was used to determine the volume weight and specific mass (actual density) of the material. Standard oven was used for moisture determination. Liquid toluene $(\mathrm{C} 7 \mathrm{H} 8)$ was preferred as the displacement material for volume measurement in specific mass measurements. Distilled water as conditioning and moistening material, lockable nylon bags are used to group conditioned and moistened canola seeds and keep them at desired moisture levels. During the trials and measurements, a home-type refrigerator was used to store the trial material at a constant temperature of $+4{ }^{\circ} \mathrm{C}$. Digital image processing and analysis software ImageJ / Fiji 1.47v and Myriad v8.0 softwares were used to determine projection areas. The wind tunnel device and the speed meter (anemometer) with a sensitivity of $0.1 \mathrm{~m} / \mathrm{s}$ were used in the measurement of terminal velocity. The roots blower (LT-65 type, max. $80 \mathrm{kPa}$, max. $2250 \mathrm{~min}-1$ produced by UKA, Konya, Turkey) was used to deliver air through the system.

\subsection{Methods}

In the research, 3 moisture values $(6.36 \%, 16.54 \%$ and $25.94 \%)$ were used. The natural moisture content of canola seeds was measured as $6.36 \%$. To increase the moisture of canola seeds to two other moisture values, water was added to the canola seeds according to the formula below.

$$
\mathrm{Q}=\frac{\mathrm{W}_{\mathrm{i}}\left(N_{f}-N_{i}\right)}{\left(100-N_{f}\right)}
$$

Where; Q, amount of water to be added $(\mathrm{kg})$; Wi, the initial mass of the material $(\mathrm{kg})$; $\mathrm{Ni}$, the initial moisture content of the material (\% w.b.); Nf, the final moisture content of the material after water addition (\% w.b.).

In the moistening of canola seeds, after adding water to the seeds, seeds were mixed regularly at a constant temperature of $+4{ }^{\circ} \mathrm{C}$ three times a day. This process was continued for two weeks. At the end of the second week, moisture was measured. In order to determine the physicomechanical properties of canola seeds, three replicate measurements were made at each moisture level. 
The following formulas were used to determine the physical properties of canola grains (Mohsenin 1986; Sitkei 1986; Çalışır et al. 2005; İzli et al. 2009; Razavi et al. 2009).

Arithmetic mean diameter: $\mathrm{D}_{\mathrm{a}}=\frac{(\mathrm{L}+2 \mathrm{~T})}{3}$

Geometric mean diameter: $\mathrm{D}_{\mathrm{g}}=\left(\mathrm{LT}^{2}\right)^{1 / 3}$

Grain volume: $V_{k}=\frac{\pi \mathrm{LT}^{2}}{6}$

Projection area: $S_{a}=\pi\left(\frac{T}{2}\right)^{2}[x z-$ plane $]$

$S_{a}=\pi\left(\frac{L}{2}\right)\left(\frac{T}{2}\right)^{2}$ [xy ve yz - planes $]$

Sphericity: $\varnothing=\left(\mathrm{LT}^{2}\right)^{1 / 3} \mathrm{~L}$

Flatness: $\varphi=1-\frac{\mathrm{T}}{\mathrm{L}}$

Where; $L$, length $(\mathrm{mm}) ; T$, thickness $(\mathrm{mm}) ; S_{a}$, projection area $\left(\mathrm{mm}^{2}\right) ; D_{g}$, geometric mean diameter $(\mathrm{mm}) ; D_{a}$, arithmetic mean diameter $(\mathrm{mm}) ; \emptyset$, equivalent sphere diameter sphericity $(\%) ; \varphi$, flatness; $V_{k}$, grain volume $\left(\mathrm{mm}^{3}\right)$. Since the thickness $(\mathrm{T})$ of the canola in the measurements shows very close values with its width (W), the thickness dimension was accepted as equivalent to the width dimension $(\mathrm{T}=\mathrm{W})$.

The true density $\left(\rho_{t}\right)$ is determined by the ratio of grain mass to the volume of the grain without voids (Mohsenin 1986; Sitkei 1986). Toluene $\left(C_{7} H_{8}\right)$ ( was used instead of water in determining the volume of the grain. Bulk density $\left(\rho_{b}\right)$ was obtained by dividing the natural (void) volume of the material by the weight of the material. The following equation was used in the calculation of the equivalent sphere diameter $\left(D_{e}\right)$ (Gorial \& O'Callaghan 1990).

$\mathrm{D}_{\mathrm{e}}=\left[\left(\frac{\mathrm{M}_{\mathrm{d}}}{\rho_{\mathrm{t}}}\right)\left(\frac{6}{\pi}\right)\right]^{1 / 3}$

Where; $M_{d}$, mass of canola seed $(\mathrm{kg}) ; \rho_{t}$, true density of canola seed $\left(\mathrm{kg} \mathrm{m}^{-3}\right)$, Porosity was found using the following equation.

$\varepsilon=100\left(1-\frac{\rho_{\mathrm{b}}}{\rho_{\mathrm{t}}}\right)$

Where; $\rho_{b}$, bulk density of canola seed $\left(\mathrm{kg} \mathrm{m}^{-3}\right) ; \rho_{t}$, true density of canola seed $\left(\mathrm{kg} \mathrm{m}^{-3}\right)$

The wind tunnel created by using the pneumatic conveyor was used to measure terminal velocities of canola grains and a digital anemometer with a speed measurement accuracy of $0.1 \mathrm{~m} \mathrm{~s}^{-1}$ was used. The drag coefficient of the canola seed's aerodynamic properties was calculated using the equations given below.

$C_{d}=\frac{2 F_{d}}{S_{a} V_{t}^{2} \rho_{a}}=\frac{2 G_{d}}{S_{a} V_{t}^{2} \rho_{a}}$

$\mathrm{G}_{\mathrm{d}}=\mathrm{M}_{\mathrm{d}} \cdot \mathrm{g}$

$\mathrm{F}_{\mathrm{d}}=\mathrm{G}_{\mathrm{d}}$

Where; $S_{a}$, projection area of the grain $\left(\mathrm{mm}^{2}\right)$; Vt, terminal velocity $\left(\mathrm{m} \mathrm{s}^{-1}\right)$; $\rho$ a, density of air $\left(1.28 \mathrm{~kg} \mathrm{~m}^{-3}\right)$; $\mathrm{Gd}$, seed weight $(\mathrm{N})$; Fd, seed drag force $(\mathrm{N})$; Md, seed mass $(\mathrm{kg})$; g, gravity acceleration $\left(9.81 \mathrm{~m} \mathrm{~s}^{-2}\right)$.

Pressure transmitters (model: HUBA 0-1600 mb) were used to determine the pressure drops in the pipe. The measured values observed on DIN-Vscreen of ESM-400 48x90 device. Trials were carried out at 3 different humidity $(6.36 \%, 16.54$ and 25.94$)$, 5 compressor cycles $\left(850,1150,1450,1750\right.$ and $\left.2250 \mathrm{~min}^{-1}\right), 3$ different pipe diameters $(43.1,54.5$ and $70.3 \mathrm{~mm})$ and 3 different material flows $\left(3.89,5.47\right.$ and $\left.7.49 \mathrm{t} \mathrm{h}^{-1}\right)$. The moisture values of canola seed have been chosen considering the storage humidity of the canola seed. Different compressor speeds have been selected by considering the conveying velocity of the canola seed. Pipe diameters were chosen according to Güner (2006). 
The trials were made with 3 replications. The difference of the pressure values before the feeder (M1) and before the cyclone (M5) at the blower outlet in the pneumatic conveyor is taken as the total pressure drop value. The air velocity in the pneumatic system was calculated from the following equation using the air flow values given in the catalogue of Longtech brand LT-65 type roots blower compressor (Güner 2006).

$\mathrm{V}_{\mathrm{a}}=\frac{4 \mathrm{Q}_{\mathrm{h}}}{60 \pi \mathrm{D}^{2}}$

Where; Va , air velocity $\left(\mathrm{m} \mathrm{s}^{-1}\right)$; Qh, air flow rate $\left(\mathrm{m}^{3} \mathrm{~min}^{-1}\right)$; $\mathrm{D}$, pipe diameter $(\mathrm{m})$

Seamless pipes made of St 37 steel material with $43.1 \mathrm{~mm}, 54.5 \mathrm{~mm}$ and $70.3 \mathrm{~mm}$ inner diameters were used as the conveying line in the trials. Power consumption has been found with the help of the following equation.

$\mathrm{N}=\sqrt{3} \mathrm{U} \cdot \mathrm{I} \cdot \operatorname{Cos} \varphi$

Where; N, power (W); U, voltage (V); I, current (A); Cos $\varphi$, power factor

In this study, two of the image processing software tools were used to determine the surface projection areas of canola seeds. The first of the computer aided image processing software tools is Myriad v8.0 digital image processing package. Along with this package, the complementary equipment specified below was also used to capture images of 30 grains randomly selected from material samples in each moisture content. Supplementary equipment used are Nikon D40X Model 10.1 megapixel SLR digital camera, appropriate size scale calibration plate, and Myriad v8.0 digital image processing software. Another computeraided image processing software tool used in the study was ImageJ / Fiji 1.47v. Once again, numerical images of 30 canola seed grains randomly selected from each moisture content sample batch were taken using the appropriate sized scale calibration plate and digital camera. Subsequently, digital images of all seed grain taken with a digital camera; Transferred and processed for processing to a computer installed with ImageJ / Fiji 1.47v software. Minitab Statistical Software was used to evaluate the results statistically (MINITAB 2018).

\section{Results and discussion}

\subsection{Physical properties of canola seeds}

Results related to the physical properties of canola seeds in three different moisture content are given in Table 1.

Table 1- Physical properties of canola seeds

\begin{tabular}{|c|c|c|c|}
\hline \multirow{2}{*}{ Physical properties } & \multicolumn{3}{|c|}{ Moisture contents (wet basis, \%) } \\
\hline & 6.36 & 16.54 & 25.94 \\
\hline \multicolumn{4}{|l|}{ Dimensional properties (mm) } \\
\hline Length & $2.14 \pm 0.011 \mathrm{~A}^{* *}$ & $2.195 \pm 0.009 \mathrm{~A}$ & $2.271 \pm 0.011 \mathrm{~B}$ \\
\hline Thickness $=$ Width & $1.83 \pm 0.0097 \mathrm{~B}^{* *}$ & $1.952 \pm 0.0079 \mathrm{~A}$ & $2.007 \pm 0.0005 \mathrm{~A}$ \\
\hline Arithmetic mean diameter & $1.93 \pm 0.0086 C^{* *}$ & $2.033 \pm 0.0073 \mathrm{~B}$ & $2.095 \pm 0.0080 \mathrm{~A}$ \\
\hline Geometric mean diameter & $1.928 \pm 0,0087 \mathrm{C}^{* *}$ & $2.03 \pm 0.0074 \mathrm{~B}$ & $2.09 \pm 0.0080 \mathrm{~A}$ \\
\hline Equivalent sphere diameter & 1.05 & 1.949 & 2.034 \\
\hline \multicolumn{4}{|l|}{ Mass properties } \\
\hline Thousand grain mass $(\mathrm{g})$ & $3.81 \pm 0.012 \mathrm{C}^{* *}$ & $4.195 \pm 0.038 \mathrm{~B}$ & $4.697 \pm 0.072 \mathrm{~A}$ \\
\hline Bulk density $\left(\mathrm{kg} / \mathrm{m}^{3}\right)$ & $643 \pm 0.0176 \mathrm{~A}^{* *}$ & $621.2 \pm 2.06 \mathrm{~B}$ & $597.8 \pm 0.521 \mathrm{C}$ \\
\hline True density $\left(\mathrm{kg} / \mathrm{m}^{3}\right)$ & $1041.66 \pm 0.887 C^{* *}$ & $1064 \pm 0.263 \mathrm{~B}$ & $1075.2 \pm 0.658 \mathrm{~A}$ \\
\hline Seed (grain) volume $\left(\mathrm{mm}^{3} / \mathrm{seed}\right)$ & $3.75 \pm 0.0504 C^{* *}$ & $4.379 \pm 0.0452 \mathrm{~B}$ & $4.79 \pm 0.0531 \mathrm{~A}$ \\
\hline Sedd(grain) mass (g) & 0.00381 & 0.004168 & 0.004688 \\
\hline \multicolumn{4}{|l|}{ Shapes properties } \\
\hline Sphericity $(\%)$ & $0.91 \pm 0.0034 \mathrm{C}^{* *}$ & $0.924 \pm 0.0025 \mathrm{~A}$ & $0.921 \pm 0.0029 \mathrm{~B}$ \\
\hline Flatness $(\%)$ & $0.145 \pm 0.0048 \mathrm{~A}^{* *}$ & $0.111 \pm 0.0036 \mathrm{C}$ & $0.116 \pm 0.0042 \mathrm{~B}$ \\
\hline Porosity $(\%)$ & $\begin{array}{l}38.27 \\
38\end{array}$ & 42.22 & 44.40 \\
\hline Projection area $\left(\mathrm{mm}^{2}\right)-[\mathrm{x}$-plane]-from equation & $3.597 \pm 0.0375 \mathrm{~A}^{* *}$ & $3.784 \pm 0.0317 \mathrm{~A}$ & $4.05 \pm 0.0375 \mathrm{~B}$ \\
\hline Projection area $\left(\mathrm{mm}^{2}\right)-[\mathrm{y} ; \mathrm{z}$-planes] -from equations & $3.076 \pm 0.0269 \mathrm{C} * *$ & $3.365 \pm 0.0236 \mathrm{~B}$ & $3.579 \pm 0.0269 \mathrm{~A}$ \\
\hline Projection area $\left(\mathrm{mm}^{2}\right)$-ImageJ $1.47 \mathrm{v}$ from package program & $\begin{array}{c}3.070+187 \\
3.020\end{array}$ & $\begin{array}{l}3.50 J+0.02 J 0 D \\
3.480\end{array}$ & 3.614 \\
\hline Projection area $\left(\mathrm{mm}^{2}\right)$-Myriad v8.0 from package program & $2.430 \pm 0.0005 \mathrm{C}^{* *}$ & $3.100 \pm 0.0006 \mathrm{~B}$ & $3.380 \pm 0.0007 \mathrm{~A}$ \\
\hline \multicolumn{4}{|l|}{ Aerodynamic properties } \\
\hline Terminal velocity (m/s) (Özlü and Güner 2016) & $5.8336 \pm 0.0674 \mathrm{C}^{* *}$ & $6.8773 \pm 0.0472 \mathrm{~B}$ & $7.3064 \pm 0.0619 \mathrm{~A}$ \\
\hline Drag coefficient & 0.5418 & 0.4701 & 0.4030 \\
\hline
\end{tabular}

**: The differences between the values given in the same lines with the same letters are statistically insignificant $(\mathrm{P} \leq 0.001)$ 
From the findings in Table 1, it is seen that the length, width, arithmetic and geometric mean diameters increase with moisture content. Duc et al. (2008 determined that the geometric mean diameter in canola increases with moisture content. Ünal \& Sincik (2009) found in their study with 3 different canola varieties (Capitol, Jetneuf and Samurai) that as the moisture increases, the length, thickness, geometric mean diameter and thickness values increase. They reported that longitudinal dimension, thickness (or diameter) and geometric mean diameter for 7.3\%, 7.7\%, and 8.3\% d.b are $2.25 \mathrm{~mm}, 1.82 \mathrm{~mm}, 1.96 \mathrm{~mm} ; 2.26 \mathrm{~mm}, 1.85 \mathrm{~mm}$, $1.98 \mathrm{~mm}$ and $2.46 \mathrm{~mm}, 1.96 \mathrm{~mm}, 2.11 \mathrm{~mm}$, respectively.

Işık \& İzli (2016) reported that the thickness, diameter, arithmetic and geometric diameter increased in the yellow split lentil as the moisture increased at 5 different moisture values. Baran et al. (2016) found that length, width and mean geometric diameter values in canola with $8.34 \%$ moisture content as $2.35 \mathrm{~mm}, 1.93 \mathrm{~mm}$ and $2.07 \mathrm{~mm}$, respectively. In the experiments, while the seed moisture content increased from $6.36 \%$ to $25.94 \%$, it was observed that the weight of 1000 grains varied between 3.81 g, $4.195 \mathrm{~g}$ and $4.697 \mathrm{~g}$, respectively, and it was determined that the weight of one thousand grain increased with moisture. As the moisture content increased, the weight of 1000 grains increased due to the canola grains absorb water and their weight increased. The following relationship was found between 1000 grain weight and moisture.

$M_{1000 d}=0.0033+0.0004 M_{c}$

Where; $M_{1000 d}$, thousand grain mass $(\mathrm{g}) ; M_{c}$, moisture content $(\%$, w.b.)

Similar results for thousand grain weights were recorded for canola, moringa oleifera, green wheat, soybeans, and chickpeas by other researchers (Aviara et al. 2013; Al-Manash \& Rababah 2007; Duc et al. 2008; Ünal \& Sincik 2009). The seed volumes of canola seeds increased with increasing moisture and similar results were found by Ünal and Sincik (2009). As the moisture content increased, the bulk volume of canola seeds decreased and their true density increased. However, if the moisture content increased to $25.94 \%$, the increase in the true density was observed to be relatively slow.

While the moisture content of canola seed (w.b.) increased from $6.36 \%$ to $16.54 \%$, the sphericity increased from $91.00 \%$ to $92.40 \%$, but it was found $92.10 \%$ when the moisture content increased to $25.94 \%$. Similar results were reported for barley by Sologubik et al. (2013) and for Okra by Sahoo \& Srivastava (2002). Duc et al. (2008) reported that the sphericity decreased from 0.946 to 0.927 with the increase in moisture content. Ünal and Sinc1k (2009) gave the sphericity values of canola $86.1 \%, 87.4 \%$ and $86.8 \%$ for $8.3 \%, 7.7 \%$ and $7.3 \%(\mathrm{db})$ of moisture content, respectively. Işı \& İzli $(2016)$ found that the sphericity increased with the increase of moisture in the yellow split lentil. Baran et al. (2016) determined the sphericity of canola as $88 \%$ for $8.34 \%$ moisture content. The sphericity of canola seeds on the contrary of flatness, firstly decreased and then increased as the moisture content increased. If the moisture content increased from $6.36 \%$ to $16.54 \%$, the porosity increased from $38.27 \%$ to $41.62 \%$. On the other hand, with the increase of moisture content from $16.54 \%$ to $25.94 \%$, porosity increased to $44.40 \%$ with an increase of $2.78 \%$. The relationship between moisture content and porosity has been determined as follows. According to this relationship, there is a polynomial relationship between moisture and porosity.

$\varepsilon=34.64+0.6437 M_{c}-0.0111 M_{c}^{2} R^{2}=99.7$

Where; $\varepsilon$, porosity $(\%) ; M_{c}$, moisture content (\%, w.b.)

Damian (2014) found that there is a polynomial relationship between the porosity and moisture contents of mustard seeds. Ünal and Sincık (2009) found porosity values of 36.6\%, 41.5\% and 38.4\% of canola seeds in $8.3 \%$, 7.7\% and $7.3 \%$ moisture contents, respectively. As the moisture content increased, projection areas increased in the XZ, XY and XZ-planes.

While the moisture content values were $6.36 \%, 16.54 \%$ and $25.94 \%$, the terminal velocities of canola seeds were $5.8336 \mathrm{~m}$ $\mathrm{s}^{-1}, 6.8773 \mathrm{~m} \mathrm{~s}^{-1}$ and $7.3064 \mathrm{~m} \mathrm{~s}^{-1}$, respectively, and terminal velocities increased with the moisture content (Özlü \& Güner 2016). Duc et al. (2008) found that terminal velocities increased from $3.47 \mathrm{~ms}^{-1}$ to $3.91 \mathrm{~ms}^{-1}$ with moisture $(10.03 \%, 14.91,20.07$, 25.06 and 30.12) in canola seeds. Kroulik et al. (2016) found the terminal velocity value for canola in $7.65 \mathrm{~ms}^{-1}$ at a moisture content of $8.3 \%$ (w.b.) in a study.

Bilanski et al. (1962) gave the terminal velocity of the canola as $7.62 \mathrm{~ms}^{-1}$. It has been determined that terminal velocity increases as the moisture content increases in apricot kernels, chickpeas and hemp seed (Gezer et al. 2002; Konak et al. 2002; Saçılık et al. 2003). The drag coefficient $\left(\mathrm{C}_{\mathrm{d}}\right)$ was $0.5418,0.4701$ and 0.4030 at $6.36 \%, 16.54 \%$ and $25.94 \%$ moisture contents, respectively. The drag coefficient decreased as the moisture content increased. The relationship between drag coefficient and moisture content was found as follows.

$$
C_{d}=0.58703-0.00709 M_{c} \quad R^{2}=0.99
$$

Where; $C_{d}$, drag coefficient, $M_{c}$, moisture content $(\%$, d.b) 


\subsection{Conveying characteristics of canola seeds}

The pneumatic conveying characteristics of the canola seed, which are obtained in three different moisture contents, 3 different pipe diameters, 3 different feed flow rates and 5 different air velocities, can be examined as follows.

\subsubsection{The effect of pipe diameter on pressure drop}

Pressure drop measurements at $16.54 \%$ and $25.9 \%$ moisture content could not be done with $43.1 \mathrm{~mm}$ and $54.5 \mathrm{~mm}$ diameter pipes due to clumping, jamming and blockages. The pressure drops of the canola with $6.36 \%$ moisture content measured in different pipe diameters at a conveying capacity of $3.89 \mathrm{t} \mathrm{h}^{-1}$ are shown in Figure 2. It is seen that the pressure drop decreases as the pipe diameter increases and air velocity decreases. Kılıçkan \& Güner (2006) found that pressure drop decreased with increasing pipe diameter for cotton seed of Gülerbey and Nazilli $84 \mathrm{~S}$ varieties at a given conveying capacity and air velocity. Kılıçkan \& Güner (2010) reported that pressure drop for pneumatic conveying of chickpea of the variety Koçbasi decreases as the pipe diameter increases at a constant conveying capacity and revolution of the blower.

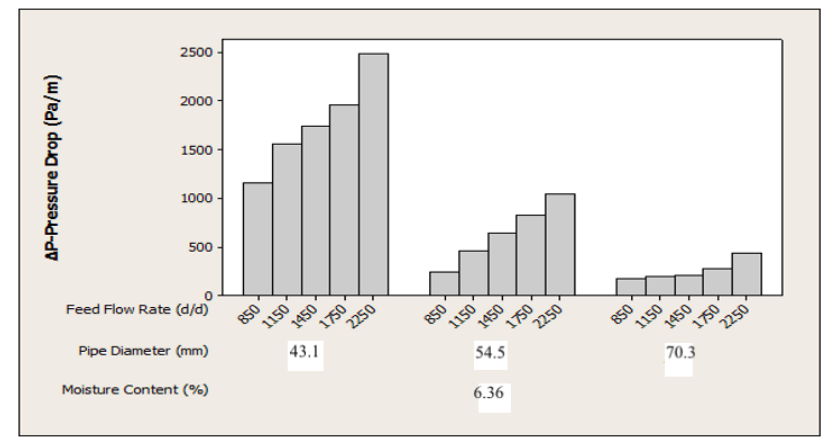

Figure 2- Effect of air velocity and pipe diameter on pressure drop at a moisture content of $6.36 \%$ and at a conveying capacity of 3.89 th$^{-1}$

\subsubsection{Effect of conveying capacity on pressure drop}

While examining the effect of conveying capacity on pressure drop; air velocity, pipe diameter and moisture content values were kept constant and pressure drops were determined due to capacity change (Figures 3-5). When the graphs are examined, it is seen that the pressure drop increases as the conveying capacity increases. Some other researcher found that the pressure drop increased as the conveying capacity increased for barley, sunflower, lentil, wheat, chickpea, and cotton seed (Güner 2006, Kılıçkan \& Güner 2006; Kılıçkan \& Güner 2010). When Figure 3 is examined the feed flow rate is $5.47 \% \mathrm{t} / \mathrm{h}$, as the air velocity increases, the pressure drop also increases, but the tendency to increase is less than the other 2 values. This may be due to the fact that the pneumatic transmission depends on many factors such as the delivery air temperature, humidity, condition of the material, feeding of the material and the like.

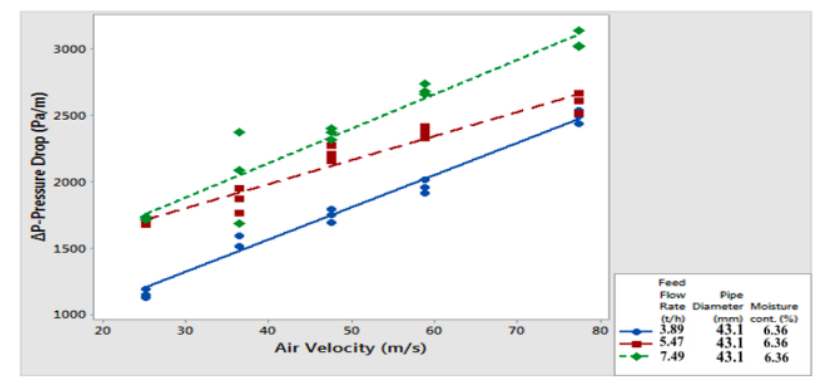

Figure 3- Pressure drop values for a pipe diameter of $43.1 \mathrm{~mm}$, a moisture content of $6.36 \%, 5$ different air velocities, and 3 different feed flow rates 


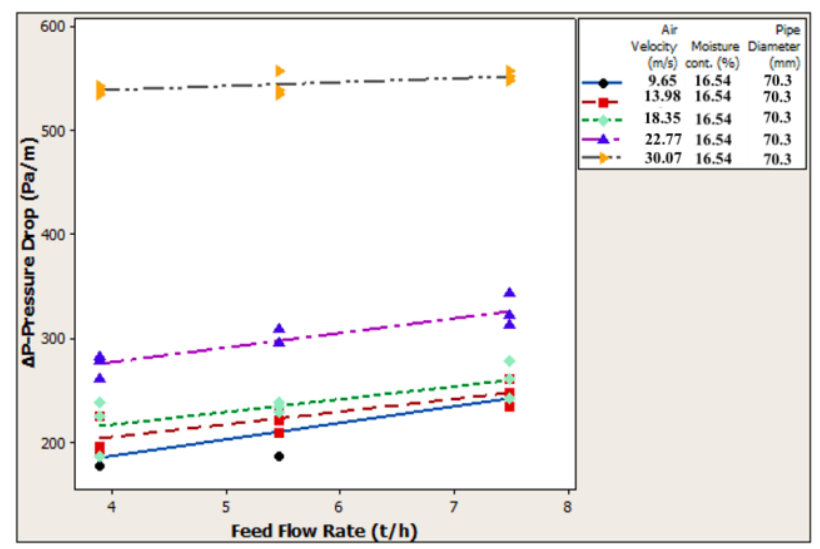

Figure 4- Pressure drop values for a pipe diameter of $70.3 \mathrm{~mm}$, a moisture content of $16.54 \%, 5$ different air velocities, and 3 different feed flow rates

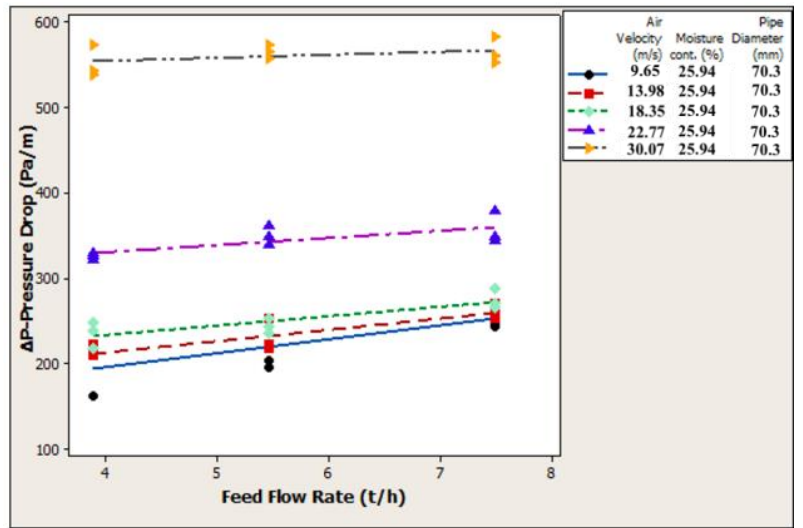

Figure 5- Pressure drop values for a pipe diameter of $70.3 \mathrm{~mm}$, a moisture content of $25.94 \%, 5$ different air velocities, and 3 different feed flow rates

\subsubsection{Moisture content and pressure drop relationships}

No pressure losses could be determined at $16.54 \%$ and $25.94 \%$ humidity values and $43.1 \mathrm{~mm}$ and $54.5 \mathrm{~mm}$ pipe diameters due to clumping and clogging. Therefore, trials could not be done. Pressure drops for a pipe diameter of $70.3 \mathrm{~mm}$ and 3 different moisture contents is given in Figure 6. Pressure drops for a pipe diameter of $70.3 \mathrm{~mm}$ increased as moisture content of canola seed increased.

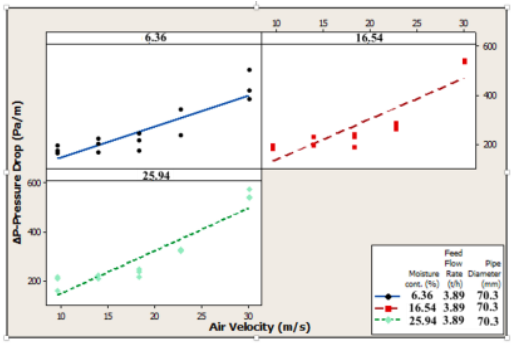

(a)

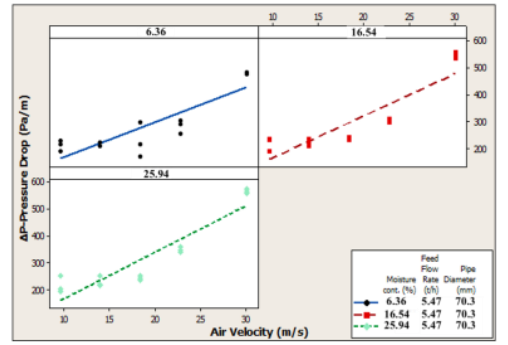

(b)

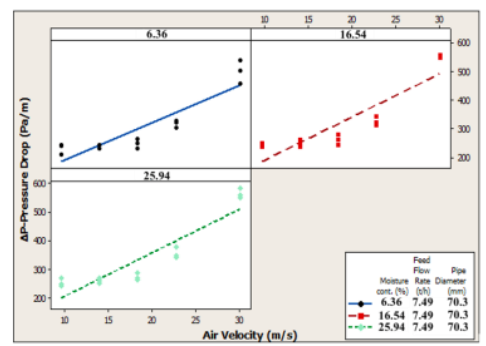

(c)

Figure 6- Pressure drops for a pipe diameter of $70.3 \mathrm{~mm}, 3$ different moisture contents, 3 different feed flow rates, and 5 different air velocities

\subsubsection{Air velocities and power consumption relationships in material conveying}

Power consumption (N) of canola seeds for a diameter pipes of $70.3 \mathrm{~mm}, 3$ different moisture contents, and 5 different air velocities are given in Figure 7. Power consumptions increase as air velocities increase. Güner and K1lıçkan found that the power consumption increased as the air velocities increased for barley, sunflower, lentil, wheat, chickpea, and cotton seed (Güner 2006, Kılıçkan \&Güner 2006; Kılıçkan \& Güner 2010). 


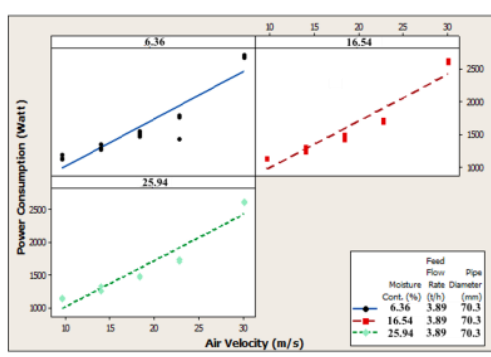

(a)

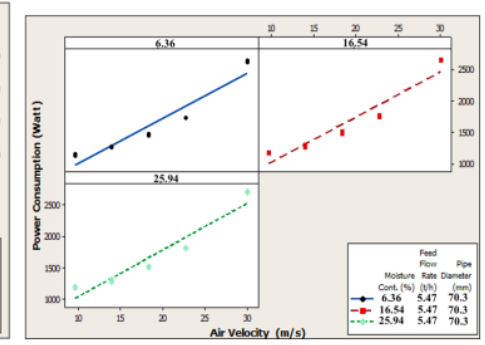

(b)

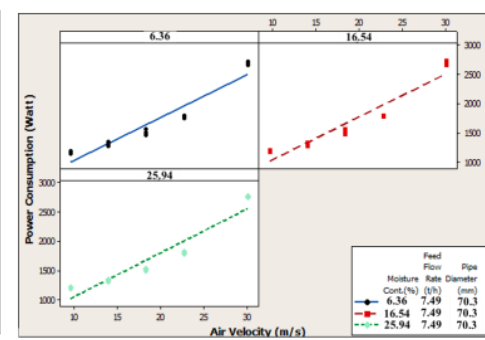

(c)

Figure 7- Power consumption for a diameter pipes of $70.3 \mathrm{~mm}, 3$ different moisture contents, 3 different feed flow rates, and 5 different air velocities [a: $Q_{m}=3.89 \mathrm{t} / \mathrm{h}, \mathrm{b}: Q_{\mathrm{m}}=5.47 \mathrm{t} / \mathrm{h}, \mathrm{c}: \mathrm{Qm}_{\mathrm{m}}=7.49 \mathrm{t} / \mathrm{h}$ ]

\subsubsection{Pipe diameter, air velocity, and power consumption relationships}

The relations between air velocity, feed flow rate (conveying capacity), pipe diameter and power consumption are given in Figure 8 when the moisture content is $6.36 \%$. While the moisture content was $6.36 \%$, the power consumption decreased as the pipe diameter increased. The reduction in power consumption was less in pipes with a diameter of $54.5 \mathrm{~mm}$ and pipes with a diameter of $70.3 \mathrm{~mm}$. Kilıçkan and Güner (2010) found that the power decreased as the pipe diameter increased in the pneumatic conveying of chickpeas. They reported that large diameter pipes should be selected for low power consumption. The results of Kılıçkan and Güner (2010) overlap with our results. As the pipe diameter increases, the friction loss (pressure drop) decreases and this decreases the power consumption. It is an expected result.

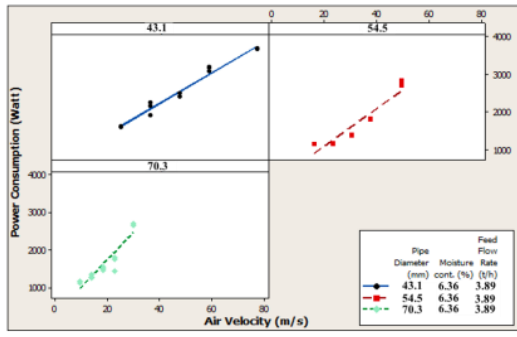

(a)

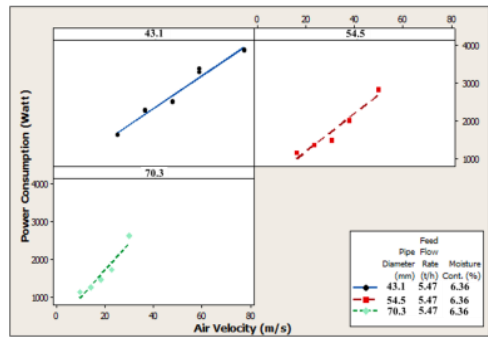

(b)

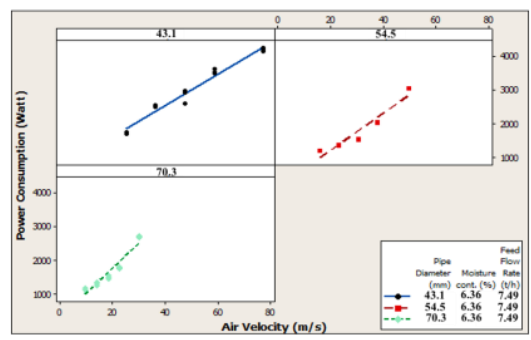

(c)

Figure 8- Power consumptions depending on pipe diameter, conveying capacity and air velocity under material moisture content of $6.36 \%\left[\mathrm{a}: \mathrm{Q}_{\mathrm{m}}=3.89 \mathrm{t} / \mathrm{h}, \mathrm{b}: \mathrm{Q}_{\mathrm{m}}=5.47 \mathrm{t} / \mathrm{h}, \mathrm{c:} \mathrm{Q}_{\mathrm{m}}=7.49 \mathrm{t} / \mathrm{h}\right]$

\subsubsection{Feed flow rates (conveying capacity) and power consumption relationships}

While the pipe diameters are constant, power consumption for 5 different air velocities, a moisture content of $6.36 \%$, and feed flow rates of $3.89 \mathrm{th}^{-1}, 5.47 \mathrm{th}^{-1}$ and $7.49 \mathrm{th}^{-1}$ is given in Figure 9. According to the data in the graph, the power consumption increases as feed flow rate increases. This is normal because the higher the feed flow rate, the more resistance the material applies to the airflow.

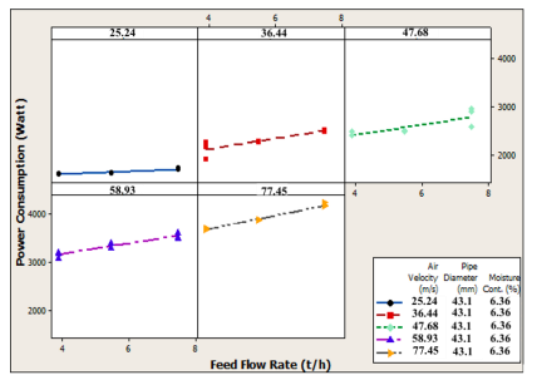

(a)

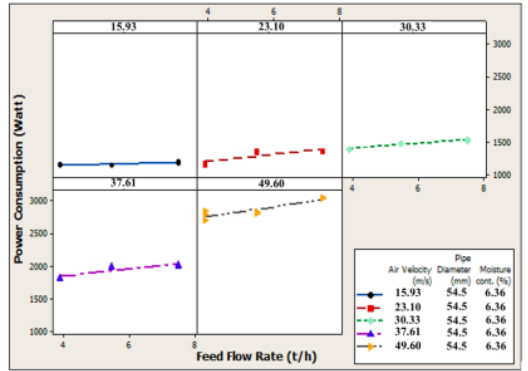

(b)

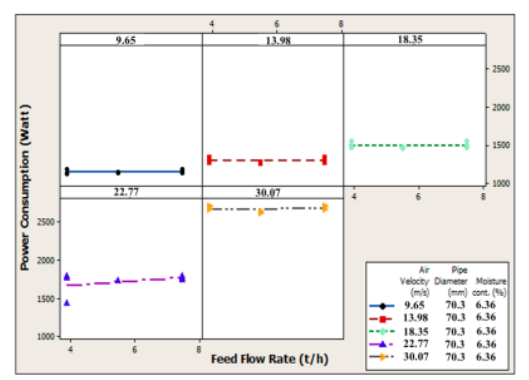

(c)

Figure 9- Power consumption for a moisture content of $6.36 \%, 3$ different diameter pipes, 3 different feed flow rates, and 5 different air velocities [a: $D=43.1 \mathrm{~mm}, \mathrm{~b}: \mathrm{D}=\mathbf{5 4 . 5} \mathrm{mm}$, c: $D=70.3 \mathrm{~mm}$ ]

\section{Conclusions}

The following results can be listed on the pneumatic conveying characteristics of the Turan variety canola seeds depending on the moisture content. 
1. Physico mechanical properties such as length, thickness, width, arithmetic and geometric mean diameter, projection area, volume, sphericity, flatness, equivalent sphere diameters, terminal velocity, porosity increase as the moisture content increases. The effect of moisture content on physical properties was found significant $(\mathrm{P} \leq 0.001)$.

2. The results of the projection areas found by different methods (ImageJ / Fiji 1.47v and Myriad v8.0 software) were found close to each other and this result led to the conclusion that these methods can be used in small size and soft textured materials.

3. Adhesion, clustering and jamming occurred in the conveying of the canola seed with moisture content values of $16.54 \%$ and $25.94 \%$ for pipes of $40.3 \mathrm{~mm}$ and $54.5 \mathrm{~mm}$ diameter, and therefore measurements could not be made. The reason why the canola seed cannot be transported under these conditions is the large pipe diameter and high moisture content of the canola seed. The high moisture content of the canola seed and the small diameter of the pipe led to sticking, clumping and high friction loss, which led to blockages. For this reason, material conveying trials at $16.54 \%$ and $25.94 \%$ moisture contents have been carried out with a pipe diameter of $70.3 \mathrm{~mm}$ and the tests have been evaluated over these outputs.

4. The increase in air velocity and feed flow rate increased pressure drop and power consumption. As the pipe diameter increased, pressure drop and power consumption decreased.

5. In order for the pressure drop to be the least, the air velocity should be chosen as small as possible and the pipe diameter should be chosen as large. In addition, care should be taken to keep the directional changes in the pneumatic system to a minimum.

6. Pneumatic conveying of materials such as canola seeds, which is high in oil content and high adhesion probability than natural storage moisture contents (such as $16.54 \%$ and $25.96 \%$ ) is not efficient. It is recommended to use pipes of 70 mm and larger diameter in the transmission of the canola due to the low pressure drop and power consumption, and the absence of clogging and sticking.

\section{Acknowledgments}

This study was prepared based on the $\mathrm{PhD}$ thesis (Özlü 2019).

\section{References}

Al-Manash M A \& Rababah T M (2007). Effect of Moisture Content on Some Physical Properties of Green Wheat. Journal of Food Engineering 79(4): 1467-1473. https://doi.org/10.1016/j.jfoodeng.2006.04.045

Aviara N A, Power P P \& Abbas T (2013). Moisture Dependent Physical Properties of Moringa oleifera Seed Relevant in Bulk Handling and Mechanical Processing. Industrial Crops and Products 42: 96-104

Baran M F, Durgut M R, Aktaş T, Ülger P \& Kayışoğlu B (2016). Determination of Some Physical Properties of Rapeseed. International Journal of Engineering Technologies 2(2): 49-55. https://doi.org/10.19072/ijet.65255

Barekati F, Hervan E M, Rad A H S, Mohamadi G N (2019). Effect of Sowing Date and Humic Acid Foliar Application on Yield and Yield Components of Canola Cultivars. Tartm Bilimleri Dergisi-Journal of Agricultural Science 25(3): 70-78. DOI: 10.15832/ankutbd.539003

Bilanski W K, Colins S H \& Chiu C L (1962). The Behaviour of Seed Grains in a Vertical Wind Tunnel, Dept. of Engineering Science. Ontario Agricultural College. Guelph, Ontario. http://www.csbe-scgab.ca/docs/journal/5/5_1_29_raw.pdf/, (accessed 07 July 2017).

Çalışır S, Marakoğlu T, Öğüt T H \& Öztürk Ö (2005). Physical Properties of Rapeseed (Brassica napus oleifera L.). Journal of Food Engineering 69(1): 61-66. DOI: 10.1016/j.jfoodeng.2004.07.010

Damian C (2014. Physical properties of mustard seeds (Sinapis alba L.). Lucrări Ştiinţifice - Seria Zootehnie 61: 39-44

Davison E, Middendorf F J \& Bilanski W K (1975). Mechanical Properties of Rapeseed. Canadian Agricultural Engineering 17(1): 50-54

Duc L A, Han J W, Hong D J \& Keum D H (2008). Physical Properties of Rapeseed (I) and (II). DOI: 10.5307/JBE.2008.33.2.101; DOI: 10.5307/JBE.2008.33.3.173.

Gezer I, Hacıseferoğulları H \& Demir F (2002). Some physical properties of Hacıhaliloğlu apricot pit and its kernel. Journal of Food Engineering 56: 49-57. DOI: 10.1016/s0260-8774(02)00147-4

Gorial B Y \& O'Callaghan J R (1990). Aerodynamic properties of grain/straw materials. J. Agric. Eng. Res. 46: 275-290. https://doi.org/10.1016/S0021-8634(05)80132-5

Güner M (2006). Determination of Pneumatic Conveying Characteristics of Some Agricultural Crops. TÜBİTAK Project, TOGTAG 3258

Işı E \& İzli N (2016). Effects of Moisture Content on Some Physical Properties of Yellow Lentil. Tartm Bilimleri Dergisi-Journal of Agricultural Sciences 22: 307-316. https://doi.org/10.1501/Tarimbil_0000001389

İzli N, Ünal H \& Sincik M (2009). Physical and Mechanical Properties of Rapeseed at Different Moisture Content. International Agrophysics 23: $137-145$

K1lıçkan A \& Güner M (2006). Pneumatic conveying characteristics of cotton seeds. Biosystems Engineering 95(4):537-546. DOI 10.1016/j.biosystemseng.2006.08.015

K1lıçkan A \& Güner M (2010). The determination of pneumatic conveying characteristics of chickpea. Turk. J. Agric \& Forestry 34: 265274. DOI: $10.3906 / t a r-0905-32$

Konak M K, Çarman K \& Aydın C (2002). Physical properties of chick pea seeds. Biosystems Engineering 82(1): 73-78. https://doi.org/10.1006/bioe.2002.0053

Kord B, Zare H \& Hosseinzadeh A (2016).Evaluation of the mechanical and physical properties of particleboard manufactured from canola (brassica napus) straws. Maderas: Ciencia y Tecnologia 18(1): 9-18. http://dx.doi.org/10.4067/S0718-221X2016005000002 
Kroulik M, Hůla J, Rybka A \& Honzík I (2016). Pneumatic conveying characteristics of seeds in a vertical ascending airstream. Res. Agr. Eng. 62(2): 56-63. DOI: 10.17221/32/2014-RAE.

MINITAB 2018. https://www.minitab.com/en-us/products/minitab/free-trial/, (accessed 03 June 2018).

Özlü R R \& Güner M (2016). Determination of Physical Properties of Canola Seeds at Different Moisture Levels (In Turkish). Gaziosmanpaşa Üniversitesi Ziraat Fakültesi Dergisi - Journal of Agricultural Faculty of Gaziosmanpasa University, JAFAG ISSN:1300-291, E-ISSN: 2147-8848 (2016) 33 (Ek Say1),pp.10-24

Özlü R R (2019). Determinatıon of Pneumatic Conveying Characteristics of Canola. PhD Thesis (Unpublished), Ankara University Institute of Natural and Applied Sciences Department of Agriculture Machinery and Technologies Engineering

Razavi S M A, Yeganehzad S \& Sadeghi A (2009). Moisture Dependent Physical Properties of Canola Seeds. Journal of Agricultural Science Technology 11: 309- 322

Sac1lik K, Ozturk R \& Keskin R (2003). Some physical properties of hemp seed. Biosystems Engineering 86(2): 191-198. https://doi.org/10.1016/S1537-5110(03)00130-2

Sahoo P K \& Srivastava A P (2002). Physical Properties of Okra Seeds. Biosystems Engineering 83: $441-448$. https://doi.org/10.1006/bioe.2002.0129

Sologubik C A, Campanone L A, Pagano A M \& Gely M C (2013). Effect of Moisture Content on Some Physical Properties of Barley. Industrial Crops and Products 43: 762-767. DOI:10.1016/j.indcrop.2012.08.109

Ünal H \& Sincık M (2009). Comparison of Some Engineering Properties of Rapeseed Cultivars. Industrial Crops and Products 30(1): 131-136. DOI: $10.1016 /$ j.indcrop.2009.02.011

(C) 2022 by the author(s). Published by Ankara University, Faculty of Agriculture, Ankara, Turkey. This is an Open Access article distributed under the terms and conditions of the Creative Commons Attribution (CC BY) license (http://creativecommons.org/licenses/by/4.0/), which permits unrestricted use, distribution, and reproduction in any medium, provided the original work is properly cited. 